Mateusz Antosz

Uniwersytet Wrocławski

\title{
Przemoc w państwie demokratycznym
}

DOI: $10.19195 / 1643-0328.23 .4$

Słowa kluczowe: przemoc, przymus, państwo, demokracja

\section{Wprowadzenie}

Jeżeli drugą połowę XX i wiek XXI można by określić jednym hasłem, byłaby to d emo kratyzacja. Po traumatycznych przeżyciach obydwu wojen światowych nowy porządek na świecie pod przywództwem państw zjednoczonych za główny cel obrał wyrugowanie wszelkich przejawów autorytaryzmu i totalitaryzmu, dostrzegając w nich główną przyczynę największej tragedii ludzkości, jaką była II wojna światowa. W trakcie tego przedsięwzięcia zmobilizowano środki i narzędzia na niespotykaną dotąd skalę: rozruszano potężną machinę propagandową, której zadaniem było przekonanie całego świata, że indywidualizm jest „lepszy” od kolektywizmu, gospodarka wolnorynkowa jest „lepsza” od centralnie sterowanej, pluralizm jest „lepszy” od jednorodności itd. ${ }^{1}$

Operacja „zaszczepiania demokracji” na świecie trwa nadal i przybrała charakter globalny. Jej zasięg objął nawet te sfery kulturowo-polityczne, dla których pojęcie demokracji było i jest zupełnie obce historycznie i mentalnie. W dziejowym pędzie doszliśmy do momentu, w którym demokratyzacja stała się wyznacznikiem dojrzałości cywilizacyjnej. Wprowadzenie ustroju demokratycznego zapewnia awans międzynarodowy, prestiż i aprobatę międzypaństwową, nierzadko przyczyniając się do zawierania intratnych umów gospodarczo-politycznych, przynoszących wymierne korzyści materialne i dyplomatyczne. Z przekonaniem można więc powiedzieć, że demokracja i demokratyzacja życia społecznego jest w „modzie”, że wyznacza międzynarodowy trend, który należy jak najszybciej wdrożyć, aby nie wypaść z głównego nurtu, i należy tego dokonać bez względu na koszty i konsekwencje. A koszty i konsekwencje niepodjęcia próby przyswojenia „modnej postawy demokratycznej” w najlepszym wypadku kończą

${ }^{1}$ Mechanizmy, narzędzia, liczne paradoksy oraz dualizmy polityki europejskiej po II wojnie światowej wyczerpująco omawia Timothy Garton Ash, zob. idem, W imieniu Europy. Niemcy i podzielony kontynent, Londyn 1996. 
się międzynarodowym ostracyzmem - w najgorszym zaś międzynarodową interwencją zbrojną ${ }^{2}$.

Nachalność, z jaką promuje się pluralizm demokratyczny jako „jedyny i słuszny kierunek rozwoju państwa", mogłaby sugerować, że ustrój ten w sposób najefektywniejszy jest w stanie zapewnić społeczeństwu bezpieczeństwo i dostatek. Mogłoby się wydawać, że w państwie demokratycznym stosowanie przemocy nie powinno mieć ani miejsca, ani uzasadnienia, a mimo to ogniska rodzące przemoc są wciąż obecne - „jako utajone zagrożenie, a nawet jako skonkretyzowana rzeczywistośc" ${ }^{3}$. W przeciwieństwie do innych systemów i ustrojów politycznych — jak choćby systemów autorytarnych — demokracje nie znajdują usprawiedliwienia dla przemocy. Ze względu na swój pluralistyczny i liberalny charakter demokracje potępiają odwoływanie się do przemocy, traktując ją jako „zło samo w sobie" oraz dopatrując się w niej zagrożenia dla respektowania woli większości.

Historia jednak uczy, że w każdym społeczeństwie, zarówno demokratycznym, jak i niedemokratycznym, dochodzi do napięć społecznych, które wymuszają na nawet najbardziej pacyfistycznie nastawionych rządach konkretne i zdecydowane posunięcia w celu obrony przyjętych praw i norm. W brutalnej rzeczywistości demokracje pluralistyczne są nieustannie konfrontowane $\mathrm{z}$ manifestacją niezadowolenia społecznego, którego wyrazem są m.in. marsze, pochody czy strajki okupacyjne, mające wpłynąć na zmianę konkretnych decyzji polityczno-społecznych.

Jak w takiej sytuacji powinno zareagować państwo? Tematem niniejszego artykułu będzie próba odpowiedzi na powyższe pytanie. Skupię się na mechanizmach i aparaturze przymusu i przemocy w systemach demokratycznych, na znaczeniu, roli i celu stosowania przemocy oraz na konsekwencjach jej stosowania w społeczeństwie.

\section{Pojęcia demokracji, przymusu i przemocy}

Przed przejściem do zasadniczego tematu artykułu należy zdefiniować główny przedmiot badania, jakim jest demokracja. Nasuwają się kluczowe pytania: Czym jest demokracja? Jakimi przymiotami się charakteryzuje? Jak i na jakich podstawach można definiować demokrację? W literaturze przedmiotu pojęcie demokracji występuje w wielu znaczeniach. Andrzej Antoszewski w Leksykonie politologii wyróżnił trzy zasadnicze sposoby definiowania demokracji:

1) W ujęciu aksjologicznym demokracja „może być traktowana jako sposób rządzenia oparty na swoistym katalogu wartości politycznych"4 Są to przede wszystkim: wolność,

2 Do interesujących przemyśleń doszła Sylwia Nowak-Bajcar, która analizując serbską prasę z lat 19992003, zwróciła szczególną uwagę na problematykę interwencji sił NATO podczas konfliktu w byłej Jugosławii w kontekście „demokratyzacji” państw postjugosłowiańskich. Zob. eadem, Demokracja w języku prasy serbskiej 1999-2003, [w:] W poszukiwaniu nowego kanonu. Reinterpretacja tradycji kulturalnej w krajach postjugosłowiańskich po 1995 roku, red. M. Dąbrowska-Partyka, Kraków 2005, s. 140-141.

3 P. Braud, Rozkosze demokracji, Warszawa 1995, s. 131.

4 A. Antoszewski, Demokracja, [w:] Leksykon politologii, red. A. Antoszewski, R. Herbut, Wrocław 2004, s. 66. 
równość, godność człowieka, sprawiedliwość, pluralizm polityczny i społeczny oraz tolerancja. Antoszewski podkreśla, że demokracja w ujęciu aksjologicznym może być utożsamiana nie tylko ze sposobem rządzenia, ale również z systemem stosunków społecznych, „który stanowi urzeczywistnienie tych wartości”" ${ }^{2}$. Ponadto demokracja aksjologiczna cechuje się swoistą uniwersalnością i wszechstronnością funkcjonowania, dlatego też może kształtować się niezależnie we wszystkich typach wspólnot społecznych.

2) Demokracja w ujęciu proceduralnym utożsamiana jest $z$ określonym typem reżimu politycznego i związanych z nim instytucji oraz mechanizmów politycznych. Antoszewski wyjaśnia, że „obejmuje ono wskazanie zasad prawno-ustrojowych odnoszących się do struktury i funkcjonowania władzy państwowej oraz reguł rządzących procesami kreowania władzy, podejmowania wiążących decyzji oraz egzekwowania odpowiedzialności politycznej”' ${ }^{3}$. W tym ujęciu do wartości demokratycznych można zaliczyć np. zasadę suwerenności narodu (ludu), zasadę reprezentacji, podział władz, ochronę praw obywatelskich czy cykliczną odpowiedzialność polityczną w uznaniu powszechnych wyborów za główne źródło legitymacji władzy. Demokracja proceduralna pojmowana jest jako taki typ reżimu politycznego, który umożliwia wszystkim obywatelom dostęp do sfery politycznej, możliwość partycypacji politycznej oraz zakłada „odpowiedzialność rządzących przed rządzonymi"

3) Demokracja jako „realny efekt społeczny, łączący formalne reguły sprawowania władzy z treścią polityki” 8 polega na traktowaniu jej jako środka do osiągnięcia określonych celów polityczno-społecznych. Jest utożsamiana ze stabilnością społeczną, której przejawem może być m.in. likwidacja różnic społecznych czy redukcja elementu przemocy w rozwiązywaniu konfliktów polityczno-społecznych ${ }^{9}$.

Demokracja może więc być rozumiana i interpretowana w różnych wymiarach, aczkolwiek cechą wspólną zawsze pozostaje wyznawanie takich wartości, jak: szeroko pojmowana wolność i swoboda działania jednostki, równość wobec prawa, a przede wszystkim uznawanie prawa „większości” przy jednoczesnym poszanowaniu praw „mniejszości”. W politologii pojęcie demokracji jest jednak jeszcze szersze i oprócz wartości i zasad ustrojowych obejmuje również „strukturę autorytetów, formalne i nieformalne »reguły gry politycznej « oraz wynikające z nich zachowania i relacje między podmiotami polityki” ${ }^{10}$. Jak wygląda jednak problematyka stosowania przemocy w systemie demokratycznym? Zanim odpowiem na to pytanie, należy wyjaśnić różnicę pomiędzy przemocą a przy musem.

5 Ibidem.

6 Ibidem.

7 Ibidem, s. 67.

8 Ibidem.

9 Należy zwrócić uwagę, że rosnąca popularność demokratycznych haseł spotkała się również z krytyką, m.in. Hansa Kelsena, który piętnuje demokrację jako „abstrakcyjny system działań indywidualnych, uregulowanych przez porządek państwowy” i jako „fikcję ideologiczną”, ubolewając jednocześnie nad tym, że pojęcie to „w bezmyślnym, potocznym żargonie politycznym spadło do rzędu konwencjonalnych frazesów, nie roszczących sobie nawet pretensji do jakiegokolwiek określonego sensu”. Zob. idem, O istocie i wartości demokracji, Warszawa 1936.

10 Szerzej na ten temat zob. Demokracje zachodnioeuropejskie. Analiza porównawcza, red. A. Antoszewski, R. Herbut, Wrocław 2008, s. 17-21. 
W literaturze przedmiotu często spotykamy się ze stosowaniem terminu przemocy jako synonimu przymusu. Oba te pojęcia zdają się być tożsame i zbieżne definicyjnie. Przemoc interpretowana jest bowiem jako celowe użycie siły fizycznej lub psychicznej względem siebie, innych osób lub całych społeczności, z którym wiąże się wysokie prawdopodobieństwo doznania uszczerbku na zdrowiu fizycznym i/lub psychicznym skutkującego nawet śmiercią ${ }^{11}$. Przymus z kolei może być rozumiany dwojako: 1) w znaczeniu szerszym jako „wszelkie fizyczne (przemoc) i pozafizyczne środki skłaniania ludzi do posłuszeństwa"12 lub 2) w ujęciu wąskim, w którym przymus nie obejmuje przemocy,

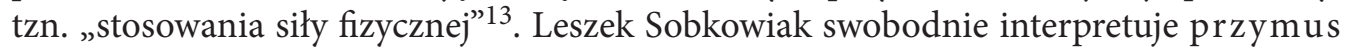
fizyczny jako przemoc, „nagą siłę”, stosowaną w sposób nagły i celowy ${ }^{14}$. Jednak czy na pewno jest to prawidłowy sposób ich pojmowania?

Przemocy i przymusu nie można traktować jako synonimów - zwłaszcza w wymiarze instytucjonalnym, państwowym. Przymus jest formą wpływania na jednostkę lub na całe społeczności, wymuszania określonego zachowania, pożądanych decyzji wbrew i/lub na przekór ich woli i interesom. Przymus posługuje się narzędziami i metodami niekoniecznie związanymi bezpośrednio z szeroko pojmowaną „przemocą”. Wszak przymus może być wynikiem powszechnie obowiązujących przepisów prawnych lub efektem społecznej presji na jednostkę, np. płacenie podatków może być odbierane jako forma „przymusu”. Podobnie jak wymuszanie „postawy kolektywistycznej” w grupie społecznej. Przymus wyróżnia się znacznie wydłużonym, „stabilniejszym” i bardziej „spłaszczonym” procesem wpływania. Oznacza to, że przymus jest pewnym ciągiem przyczynowo-skutkowym rozłożonym w czasie. W porównaniu z przemocą przymus cechuje się dłuższą „żywotnością” w przestrzeni społecznej i jest łagodniej odbierany przez opinię publiczną. Przymus charakteryzuje się celowością — przemoc z kolei może działać „ślepo”, dla samej przemocy. Przemoc jest gwałtowna, nagła - przymus natomiast dozuje natężenie i jest bardziej przewidywalny.

Przemoc, w odróżnieniu od przymusu, pojmowana jest głównie przez pryzmat „agresji”, „ofensywności”. Mimo że przemoc jest również procesem wpływania, cechuje się ona bardziej brutalną ingerencją w naruszaniu fizyczności i/lub zdrowia psychicznego jednostki. Opór zazwyczaj wzmaga intensywność przemocy, a techniki, mechanizmy, narzędzia, jakimi się posługuje, wzbudzają skrajne niezadowolenie opinii publicznej. Przemoc jest procesem przełamywania woli lub wpływania na decyzje jednostki/społeczności środkami i narzędziami, które wiążą się z godzeniem w wolność, godność i nienaruszalność człowieka. Podręcznikowym przykładem przemocy jest gwałt jako symbol ostatecznego złamania woli, upodlenia i upokorzenia w wyniku brutalnego naruszenia cielesności przy jednoczesnej dominacji fizycznej, co traumatycznie wpływa na psychikę ofiary.

Przemoc przybiera jednak różne oblicza. W wymiarze państwowym mogą to być zasady legitymowanego normatywnie panowania i wówczas jest ona immanentną cechą

\footnotetext{
11 The World Health Report 2002. Reducing Risks, Promoting Healthy Life, Genewa 2002, s. 4.

12 L. Sobkowiak, Przymus, [w:] Leksykon politologii..., s. 358.

13 Ibidem.

14 Ibidem.
} 
„władzy politycznej”15. W systemach demokratycznych odwoływanie się do przemocy traktowane jest jako „zło samo w sobie”. Eugeniusz Młyniec zwraca jednak uwagę, że w „warunkach ekstremalnych”, gdy np. „dochodzi do zagrożenia bezpieczeństwa większości społeczeństwa lub w wyniku użycia przemocy w stosunku do państwa lub obywateli, władze posiadają monopol na legalne użycie przymusu"16. Innymi słowy: tylko instytucja państwa dysponuje legalnym upoważnieniem do stosowania środków i narzędzi przemocy względem obywateli. Szerzej na ten temat w dalszej części artykułu.

Reasumując: pojęcie „demokracji” cechuje mnogość definicyjna i interpretacyjna, jednak na potrzeby niniejszej pracy skoncentruję się na zagadnieniu demokracji w ujęciu proceduralnym jako formie reżimu politycznego i wiążących się z nim mechanizmach instytucjonalnych składających się na tzw. „system państwa demokratycznego”. Nawet demokracje skonsolidowane borykają się z problematyką przemocy i przymusu. W ujęciu proceduralnym przemoc traktowana jest jako instrument instytucji państwowej legitymizujący jej władzę. Państwo posiada konstytucyjny monopol na stosowanie przemocy i przymusu względem obywateli w celu zachowania stabilności i bezpieczeństwa.

Przymus jest pojęciem szerszym od przemocy. Jest formą celowego, intencjonalnego wpływu na jednostkę w celu wymuszenia - wbrew lub na przekór jej woli - założonych decyzji czy zachowań. Przemoc z kolei może posłużyć jako narzędzie przymusu. Przemoc utożsamiana jest z gwałtownością i nieprzewidywalnością. Jest próbą ostatecznego złamania woli osoby lub społeczeństwa poprzez zastosowanie wszelkich środków nacisku, które często wiążą się z uszczerbkiem na zdrowiu fizycznym i psychicznym poszkodowanych.

\section{Państwo jako instytucja przymusu}

Na wstępie warto zauważyć, że każde państwo, bez względu na swój demokratyczny czy też niedemokratyczny charakter, jest organizacją, która posługuje się przymusem systematycznie i jawnie - na nieporównywalnie większą skalę, wobec większej liczby ludzi i spraw niż jakakolwiek inna instytucja ${ }^{17}$. Jak wyjaśnia Wojciech Lamentowicz: „państwo dąży do tego, aby stosować przymus na podstawie ogólnych norm i zachowania (prawo), a posłuszeństwo wobec swego przymusu określa jako obowiązki ludzi i organizacji działających na terytorium tego państwa" ${ }^{18}$. W tym miejscu należy zadać kluczowe pytanie: Czy i kiedy przymus przeradza się w przemoc? Można bowiem założyć, że wszelki przymus państwowy jest pochodną przemocy, co czyniłoby z organizacji państwowej największego oprawcę w dziejach ludzkości. Tak jednak nie jest. Tym, co odróżnia przymus państwa od przymusu każdej innej organizacji, jest legalność, tzn. przymus oparty na mocy powszechnie obowiązujących przepisów prawnych ${ }^{19}$. Państwo

\footnotetext{
15 Zob. J. Locke, Dwa traktaty o rządzie, Warszawa 1992.

16 E. Młyniec, Przemoc polityczna, [w:] Leksykon politologii..., s. 356.

17 W. Lamentowicz, Państwo współczesne, Warszawa 1993, s. 19.

18 Ibidem.

19 Ibidem.
} 
jest zobligowane do stosowania przymusu na wielu płaszczyznach życia społeczno-polityczno-gospodarczego lub, jak zauważa Hannah Arendt, państwo to „narzędzie przemocy w rękach klasy rządzącej”, a „faktyczna władza klas rządzących nie polega ani nie opiera się na przemocy" ${ }^{20}$. Można $\mathrm{z}$ tego wnioskować, że nie formy rządów czy ustrój polityczny, lecz państwo per se jest instrumentem, a tym samym źródłem przymusu i przemocy - bez względu na charakter systemowy. Tak więc formą przymusu państwowego jest m.in. procedura nabycia/utraty obywatelstwa, możliwość stosowania sankcji i kar za nieposłuszeństwo czy dążenie grup rządzących do wyłącznego dysponowania środkami fizycznego przymusu (policja, siły zbrojne, służby). Wszystkie te zabiegi mają na celu uniemożliwienie obywatelowi podejmowania działań niezgodnych z przyjętym prawem (np. samosądy). Zdaniem Lamentowicza „ten monopol łagodzi obyczaje, jest wyrazem cywilizacyjnego postępu zwłaszcza wtedy, gdy państwo stosuje przymus na podstawie prawa w zgodzie z prawem"21.

Bezsprzecznie każde państwo ogranicza wolność jednostki. Czy taka forma jawnego przymusu nad człowiekiem, ograniczenie jego praw natury, narzucanie mu obowiązków względem instytucji państwowych i samego państwa nie jest dostatecznym objawem przemocy? Zdaniem Maxa Webera jest. W swojej słynnej rozprawie pt. Polityka jako zawód i powołanie wyjaśnia, że posiadanie monopolu na stosowanie przemocy fizycznej jest jednym z wyznaczników teorii państwa, która zakłada, że państwowość wynika $\mathrm{z}$ legalności stosowania siły oraz wymuszania przy użyciu siły porządku, nierzadko kosztem obywatela ${ }^{22}$. Nasuwa się hipoteza, że przemoc i różne formy jej stosowania są nieodłącznym elementem każdego państwa. W państwie demokratycznym natomiast „przymusowość” ta jest niezbędna do odpowiedniego egzekwowania przepisów prawnych przez władze. Dzięki temu obywatele nie mogą stosować prawa w sposób wybiórczy, rolą państwa jest bowiem dbanie o dobro obywateli, stanie na straży prawa i porządku publicznego, a także umiejętne redystrybuowanie środków i dóbr. Państwo stosuje zatem przymus, aby nie doprowadzić do bezprawia i anarchii. Państwo demokratyczne potępia przemoc, samo jednak przymus i przemoc stosuje w celu obrony „racji stanu”, w celu obrony „demokracji”.

Jak daleko zatem może się posunąć państwo w stosowaniu przemocy? Zakładając, że każda przemoc potrzebuje „narzędzi przemocy”"23, wszystko zależy od intensyfikacji działania aparatów państwowych upoważnionych do stosowania przymusu. Państwo jako organizacja jest w stanie pozbawić obywatela majątku, wolności osobistej, a nawet życia, jeżeli ten odmówi posłuszeństwa wobec norm i decyzji organów państwowych. Teoretycznie państwo ma nieograniczoną władzę nad człowiekiem. Istotne jest więc, $\mathrm{w}$ jakim celu przemoc i przymus są stosowane wobec obywatela oraz w jakim zakresie. Owszem, państwo jest w stanie nadużywać swoich kompetencji w stosunku do praw człowieka - może tego dokonać w bardziej lub mniej jawny sposób. Ale wtedy nie

\footnotetext{
${ }^{20}$ H. Arendt, O przemocy. Niepostuszeństwo obywatelskie, Warszawa 1998, s. 13-14.

21 Ibidem.

22 M. Weber, The Theory of Social and Economic Organization, London 1964, s. 154.

${ }^{23}$ H. Arendt, op. cit., s. 4.
} 
można takiego państwa nazwać państwem prawa. Albowiem tym, co odróżnia państwo demokratyczne od totalitarnego, jest fakt, że demokracje stosują przymus i przemoc właśnie $\mathrm{w}$ obronie powszechnie obowiązującego prawa $-\mathrm{z}$ konstytucją na czele. W państwie totalitarnym natomiast przemoc i przymus mają już zupełnie inny charakter. Ponadto demokracje pluralistyczne, skupione na indywidualizmie i liberalizmie jednostki, przy pomocy środków przymusu starają się zapobiec sytuacji, w której jedna osoba ograniczałaby (usiłowałaby ograniczyć) wolność drugiej jednostki. Wolność i godność człowieka zawsze stoją na pierwszym miejscu w państwie demokratycznym, a w interesie państwa leży zabezpieczenie tych wartości w prawie.

Jednakże każda monopolizacja w życiu społecznym jest zła sama w sobie i godzi w podstawowe prawa człowieka. Paradoksalnie - demokracje pluralistyczne, które za wartości najwyższe uznają równość i wolność człowieka, w rzeczywistości są „dyktaturą większości” ${ }^{24}$ przy jednoczesnym poszanowaniu praw mniejszości. Praktyka jednak wskazuje, że prawa mniejszości są ignorowane, a wręcz łamane przy pomocy legalnych środków prawnych, jak np. głosowanie w wolnych wyborach, gdzie większość narzuca mniejszości swoje potrzeby. Dochodzi do jawnej dyskryminacji, która z kolei wywołuje niezadowolenie społeczne. Państwo demokratyczne, aby zahamować niepożądany bieg zdarzeń, aby uniknąć zastosowania radykalnych form przemocy, angażuje instytucje społeczno-kulturowe, które mają pomóc we właściwym interpretowaniu rzeczywistości są to np. Kościól, szkoły, stowarzyszenia, środki masowego przekazu itd. ${ }^{25}$ Dzięki temu zabiegowi często dochodzi do rozprężenia nastrojów społecznych bez stosowania fizycznych środków przymusu. Te z kolei powinny być stosowane $\mathrm{w}$ absolutnej ostateczności i przy stosownym uzasadnieniu poważnymi argumentami moralnymi, aby nie nakręcać spirali nienawiści i nieufności do aparatów i władzy państwowej oraz do samego systemu.

$\mathrm{Z}$ racjonalnego punktu widzenia mogłoby się wydawać, że pluralizm polityczny, tolerancja, a przede wszystkim wolność słowa i wolność medialna - ze względu na mnogość wzajemnie wykluczających się informacji, demaskowanie skandali politycznych, ukazywanie nierówności społecznych - mogłyby pogłębiać oburzenie oraz prowokować do przemocy zarówno rządzących, jak i rządzonych. Tymczasem jest zupełnie odwrotnie. Media posiłkują się banalizacją i umiarkowaniem. Kluczowe informacje polityczne i społeczne topione są $\mathrm{w}$ masie informacji o charakterze rozrywkowym i widowiskowym, tracą tym samym na ostrości konflikty społeczne i przepychanki polityczne. Konsekwencją powyższych praktyk jest rosnąca liczba niezdecydowanych i nieokreślonych politycznie obywateli. $\mathrm{Na}$ dłuższą metę budzi to w społeczeństwie sceptycyzm, a nawet nieufność i zniechęca ludzi do interesowania się najbliższym otoczeniem politycznym. Na szczęście w dobie powszechnego dostępu do Internetu znacznie łatwiej jest przejrzeć manipulacje i machinacje medialne, dzięki czemu rośnie liczba uświadomionych obywateli ${ }^{26}$.

24 S. Žižek, Przemoc. Sześć spojrzeń z ukosa, Warszawa 2010, s. 31.

25 P. Braud, op. cit., s. 132.

26 Więcej o rosnącym wpływie Internetu na życie publiczne obywateli zob. L. Haber, Społeczeństwo informacyjne. Wizja czy rzeczywistość?, Kraków 2004. 


\section{Instrumentalizacja przemocy w demokracji}

Pomimo podejmowanych przez państwo demokratyczne wszelkich środków ostrożności, każde prawo, każdy ład i struktura społeczna, prędzej czy później, rodzi konflikt na płaszczyźnie obywatel-państwo. Napięcie to ma podłoże psychologiczne - podmiot odczuwa presję związaną z przestrzeganiem przepisów prawa i zasad. Napięcie jest również stanem wewnętrznego niepokoju, którego naturalną konsekwencją jest gniew. Czołowy polski ideolog narodowy, Roman Dmowski, skomentował ten stan w sposób następujący: „Państwo jest organizacją przymusu, który sam w sobie jest rzeczą przykrą, budzącą bunt w duszy ludzkiej”27. W tej niebezpiecznej zarówno dla społeczeństwa, jak i dla państwa sytuacji „buntu dusz” nierzadko dochodzi do dylematu posłuszeństwa. Odmowa posłuszeństwa wiąże się bowiem z poważnymi konsekwencjami i wyjątkowymi kosztami, dlatego najczęstszą postawą obywatelską jest poddanie się. Philippe Braud zauważa, że w celu wyeliminowania wstydu i upokorzenia jednostki odczuwają potrzebę zastosowania jednego z dwóch scenariuszy: 1) „mogą wierzyć, że narzucona im norma zewnętrzna uzasadniona jest jakąś wyższą, nie podlegającą dyskusji, zasadą, której podlegają również inni obywatele; pozwala im to poddać się bez poczucia upokorzenia nie tyle jako sile, ile mocy prawa” lub 2) „mogą uwewnętrznić normę zewnętrzną, to jest uważać ją za swoją do tego stopnia, żeby ulegając jej mieć wrażenie podporządkowania się wymogom własnych norm moralnych lub spełnienia obowiązku obywatelskiego"28.

W tych dwóch aspektach życia społecznego demokracja pluralistyczna oferuje człowiekowi cały wachlarz możliwości „spełnienia” się w roli obywatela, jak np. uczestnictwo w życiu publicznym, zasada praworządnej działalności administracyjnej, niezależna sprawiedliwość, możliwość odwoływania się w ramach dochodzenia swych praw, równość wobec prawa itd. Wszystko to stwarza iluzoryczny obraz systemu, który zostaje zaakceptowany przez jednostkę jako swój własny, oparty na własnych etycznych zasadach. Sprzyja to dobrowolnemu poddaniu się prawu, bez groźby użycia środków przemocy i przymusu. Jak podsumował to Braud: „Pozornie zniknięcie przemocy państwowej ułatwia poddanie się prawu bez większych napięć emocjonalnych. Posłuch wynikający z przymusu znajduje swą sublimację w postaci poszanowania obowiązku"29.

W literaturze przedmiotu wyróżnia się co najmniej dwie odmiany przemocy w demokracjach pluralistycznych. Są to: 1) przemoc instrumentalna i 2) przemoc porywcza. W sposób wyczerpujący obydwa zjawiska przemocy opisuje Braud w swoim dziele pt. Rozkosze demokracji, dlatego też pozwolę sobie jedynie na streszczenie i podsumowanie przemyśleń autora $\mathrm{w}$ tej materii.

Przemoc instrumentalna w państwie pluralistycznym sprowadza się do kalkulacji politycznej, która dąży do osiągnięcia zamierzonego celu ${ }^{30}$. Władza rządząca przy pomocy monopolu legalnego przymusu podejmuje decyzję o ewentualnym użyciu siły

\footnotetext{
27 R. Dmowski, Polityka polska i odbudowanie państwa, Warszawa 2008, s. 208.

28 P. Braud, op. cit., s. 134.

29 Ibidem.

${ }^{30}$ Ibidem.
} 
w celu zapewnienia respektowania prawa i woli większości. Autor zauważa, że instrumentalizację charakteryzuje zazwyczaj użycie przemocy, np. przez siły policyjne wezwane do wymuszenia przestrzegania prawa lub przez armię mającą za zadanie obronę kraju. Powyższa forma przemocy stosowana jest również w wyniku kalkulacji ugrupowań politycznych, które w desperackiej sytuacji braku możliwości innych form argumentacji postanawiają uciec się do stosowania siły jako formy „broni ubogich”31. Autor za przykład podaje zamachy terrorystyczne, porywanie zakładników, haracze, wymuszenia itp. ${ }^{32}$

Przemoc porywcza z kolei ma znacznie mniej przewidywalny charakter. Jest konsekwencją rodzących się wewnątrzspołecznych napięć, które w poszukiwaniu ujścia skumulowanej negatywnej energii w przemocy odnajdują usprawiedliwienie dla gwałtownego wyzwolenia, bez dokonania wcześniejszego rachunku kosztów, korzyści i strat — „stąd jej pozorny irracjonalny charakter”33. Braud zauważa, że przemoc porywcza często dotyka bezstronnych aktorów, którzy niekoniecznie muszą mieć związek ze źródłami społecznej frustracji (np. represje na wszystkich obywatelach danej mniejszości narodowej). Dodatkowo autor Rozkoszy demokracji wyjaśnia:

[przemoc porywcza - MA] staje się ona przemocą polityczną wówczas, gdy frustracje społeczne, kulturalne czy ekonomiczne przyczyniają się do wzrostu gniewu wpływającego na kalkulacje aktorów życia politycznego, bez względu na to, czy gniew ten jest skierowany, czy też nie, przeciwko władzy państwowej ${ }^{34}$.

Innymi słowy: przemoc porywcza w bardzo prosty sposób może zmienić się w przemoc instrumentalną. Władza polityczna i ugrupowania polityczne (często opozycyjne) mogą wykorzystać narastające niezadowolenie społeczne do osiągnięcia własnych partykularnych celów.

\section{Podsumowanie}

Państwo demokracji pluralistycznej narażone jest na nieustanne pokusy stosowania siły w celu osiągnięcia konkretnego celu. Demonstracje, manifestacje, strajki — odwoływanie się do siły, a nawet groźba przemocy dalekie są od politycznej skuteczności. Historia uczy, że przemoc rodzi przemoc, a siła budzi gniew. W demokracjach, nawet skonsolidowanych, mamy do czynienia z epizodycznością przemocy w postaci aktów terrorystycznych, zamachów, zabójstw, porwań itd. Liczą one na rozgłos, który z kolei wzbudzi trwogę

31 Ibidem.

32 Bieżące wydarzenia na polskiej arenie politycznej mogą posłużyć za przykład instrumentalizacji przemocy przy wykorzystaniu demokratycznego narzędzia w postaci wolności zrzeszania się i publicznego manifestowania niezadowolenia z sytuacji polityczno-społecznej. Nawoływanie opozycji do „wychodzenia na ulice”, czy też wzywanie żołnierzy Rzeczpospolitej do „buntu wobec urzędu administracji rządowej” ukazują stopień bezsilności i desperacji polskiej opozycji oraz współpracujących z nią grup, które z powodu braku innych środków i możliwości nacisku politycznego uciekają się do propagowania i nawoływania do jawnej przemocy wobec organów rządzących, a tym samym do destabilizacji całego państwa.

33 P. Braud, op. cit., s. 134.

34 Ibidem. 
w społeczeństwie i wymusi na ekipie rządzącej podjęcie pożądanych decyzji politycznych. Niezadowolenie społeczne i rodzące się z niego napięcie należą do najniebezpieczniejszych dla systemu zjawisk. W demokracji pluralistycznej nierzadko opozycja stara się wykorzystać ogólne rozgoryczenie społeczne i złą sytuację gospodarczo-polityczną państwa, tłumacząc je zaniedbaniem, brakiem kompetencji, a nawet przejawem złej woli rządzących. W takiej sytuacji najlepszym „bezpiecznikiem” systemu społecznego jest odpowiedzialność polityczna i perspektywa alternacji wynikającej z cyklicznych wyborów ${ }^{35}$.

Tym, co odróżnia demokrację od innych systemów politycznych, jest prawo, które ma za zadanie regulować i normować zachowania społeczne, zapewniając bezpieczeństwo, stabilizację i poczucie sprawiedliwości. Prawo narzuca obywatelom ściśle określone zasady postępowania, obowiązki i wiążące się z nimi konsekwencje. Cechą charakterystyczną każdego państwa (bez względu na jego charakter ustrojowy) jest wyłączność w stosowaniu siły i wszelkich narzędzi związanych z przymusem i przemocą. Dzięki temu zabiegowi państwo stara się wyeliminować ze społeczeństwa zachowania „niepożądane”, które w jakikolwiek sposób naginałyby czy łamały prawo, aby zapewnić ochronę prawa i wiążących się z nim wartości, np. równości, wolności, tolerancji. Innymi słowy: przymus i przemoc w państwie demokratycznym są przykrą koniecznością, która zapewnia funkcjonowanie instytucji państwowej. Trafnie podsumował ten stan rzeczy Lamentowicz, którego cytat pragnę ująć w formie sentencji kończącej niniejszy artykuł: „Państwo prawne, stosując przymus i odbierając innym prawo jego stosowania, zadaje cierpienia, które są jednak uzasadnione przez wyrządzone zło"36.

\section{Bibliografia}

Antoszewski A., Demokracja, [w:] Leksykon politologii, red. A. Antoszewski, R. Herbut, Atla 2, Wrocław 2004. Arendt H., O przemocy. Niepostuszeństwo obywatelskie, Fundacja Aletheia, Warszawa 1998.

Ash T.G., W imieniu Europy. Niemcy i podzielony kontynent, Aneks, Londyn 1996.

Braud P., Rozkosze demokracji, Wydawnictwo Naukowe PWN, Warszawa 1995.

Demokracje zachodnioeuropejskie. Analiza porównawcza, red. A. Antoszewski, R. Herbut, Wydawnictwo Uniwersytetu Wrocławskiego, Wrocław 2008.

Dmowski R., Polityka polska i odbudowanie państwa, Muzeum Niepodległości: ZP Grupa, Warszawa 2008.

Haber L., Społeczeństwo informacyjne. Wizja czy rzeczywistość?, AGH Uczelniane Wydawnictwa Naukowo-Dydaktyczne, Kraków 2004.

Kelsen H., O istocie i wartości demokracji, Księgarnia Powszechna, Warszawa 1936.

Lamentowicz W., Państwo współczesne, Wydawnictwa Szkolne i Pedagogiczne, Warszawa 1993.

Locke J., Dwa traktaty o rzadzie, Wydawnictwo Naukowe PWN, Warszawa 1992.

Młyniec E., Przemoc polityczna, [w:] Leksykon politologii, red. A. Antoszewski, R. Herbut, Atla 2, Wrocław 2004.

Nowak-Bajcar S., Demokracja w języku prasy serbskiej 1999-2003, [w:] W poszukiwaniu nowego kanonu. Reinterpretacja tradycji kulturalnej w krajach postjugosłowiańskich po 1995 roku, red. M. Dąbrowska-Partyka, Wydawnictwo Uniwersytetu Jagiellońskiego, Kraków 2005.

Sobkowiak L., Przymus, [w:] Leksykon politologii, red. A. Antoszewski, R. Herbut, Atla 2, Wrocław 2004.

35 Ibidem.

36 W. Lamentowicz, op. cit., s. 22. 
Weber M., The Theory of Social and Economic Organization, Collier Macmillan Publishers, London 1964. The World Health Report 2002. Reducing Risks, Promoting Healthy Life, Genewa 2002.

Žižek S., Przemoc. Sześć spojrzeń z ukosa, Muza, Warszawa 2010.

\section{The violence in democratic state}

Keywords: violence, coercion, state, democracy

\section{Summary}

The democratic state - like any social-political system - have to contend with numerous forms of social tensions that force governments to take action in order to preserve organizational stability of the whole state. Democratic systems are characterized by having a number of tools and mechanisms to regulating system and/or to "the spreading" social mood, which makes it possible to "peaceful" resolutions of conflicts. However, even in consolidated and mature democracies there are situations where the state (government) resort to coercion and violence against citizens. What factors influence the making "definitive" measures? How different is the coercion between state violence? These and many other questions I will try to answer in this article. 